\title{
A Framework for the Heterogeneity and Ecosystem Services of Farmland Landscapes: An Integrative Review
}

\author{
Xiaohui Wang ${ }^{1,2}$, Yao Wu ${ }^{1,2}$, Kiril Manevski ${ }^{3,4}\left(\mathbb{D}\right.$, Manqi Fu ${ }^{1,2}$, Xiaogang Yin ${ }^{1,2}$ and Fu Chen ${ }^{1,2, *}$ \\ 1 College of Agriculture and Biotechnology, China Agricultural University, Beijing 100193, China; \\ wxhwxh@foxmail.com (X.W.); wuyao626@foxmail.com (Y.W.); 2016301010225@cau.edu.cn (M.F.); \\ xiaogangyin@cau.edu.cn (X.Y.) \\ 2 Key Laboratory of Farming System, Ministry of Agriculture and Rural Affairs, Beijing 100193, China \\ 3 Department of Agroecology, Aarhus University, 8830 Tjele, Denmark; kiril.manevski@agro.au.dk \\ 4 Sino-Danish Center of Education and Research, Beijing 101400, China \\ * Correspondence: chenfu@cau.edu.cn
}

check for

updates

Citation: Wang, X.; Wu, Y.;

Manevski, K.; Fu, M.; Yin, X.; Chen, F.

A Framework for the Heterogeneity

and Ecosystem Services of Farmland

Landscapes: An Integrative Review.

Sustainability 2021, 13, 12463.

https://doi.org/10.3390/

su132212463

Academic Editor: Alexandra

Jacquelyn Burgess

Received: 6 September 2021

Accepted: 5 November 2021

Published: 11 November 2021

Publisher's Note: MDPI stays neutral with regard to jurisdictional claims in published maps and institutional affiliations.

Copyright: (C) 2021 by the authors Licensee MDPI, Basel, Switzerland. This article is an open access article distributed under the terms and conditions of the Creative Commons Attribution (CC BY) license (https:/ / creativecommons.org/licenses/by/ $4.0 /)$.

\begin{abstract}
It is essential for the sustainable development of farmland landscapes to balance ecosystem service trade-offs and improve resource use efficiency during crop production. Thus, an integrative and concept-centric qualitative approach was applied by combining the patch-corridor-matrix model of landscape ecology and the crop layout theory of farming systems into a theoretical framework. The thesis concludes that a farmland landscape comprises three compositions: the crop (the main crop and the service crop), the non-crop, and the non-vegetation, leading to heterogeneous composition and configuration. The main crop, typically displayed as large patches with a high distribution ratio, provides most of the provisioning services, while the service crop performs many regulation services. The non-crop and non-vegetation compositions often appear as strips that can connect different patches as corridors and support the provisioning services of crops. Non-crop compositions mainly focus on support and regulation services, while non-vegetation compositions support farming operations. Further research is needed in several respects, including the ecological impact and ecosystem service trade-offs of the composition and configuration heterogeneity, and strategies for the adoption of cropping systems and agronomic measures at the landscape scale, which are essential to the evaluation, improvement, and redesign of farmland landscapes.
\end{abstract}

Keywords: farmland landscape; crop layout; composition; configuration; ecosystem services

\section{Introduction}

The first 'Green Revolution' of the mid-20th century met the food demands of millions of people worldwide while concomitantly decreasing the sustainability of farmland production due to the overuse of natural resources, the pollution of water, air, and land, the loss of biodiversity, and habitat fragmentation [1,2]. It became evident over the decades that crop production and environmental outcomes depend not only on the crop genetic performance but also on how cropping systems are managed at the field scale, as well as interactions among ecosystems across the landscape. Food production and dietary composition can be tailored by agricultural systems with different intensification levels, which influence the agro-economic performance (in terms of yield and protein content) and the environment, in particular biodiversity [3]. There is a trend in many developed and some developing countries to design agricultural systems that are both ecologically sound and economically viable [4].

A landscape is defined as a geographic entity of tens to hundreds of square kilometers with a high degree of spatial heterogeneity in an ecological context, i.e., containing mosaics of interactive ecosystems that (re)appear in a similar form [5], which emphasizes space and heterogeneity as a concept from field to region [6]. Therefore, heterogeneity is considered a basic feature of a landscape. The patch-corridor-matrix model is a fundamental and 
widely used theory in landscape heterogeneity research [5,7]. It constructs a common point for describing a landscape's structure and ecosystem services and their relationships and dynamics in the basic units of a landscape structure of patches, corridors, and matrices [7].

In agricultural landscapes, more than $60 \%$ of the area is typically dedicated to agricultural production (croplands, pastures) and associated infrastructure [8] (e.g., roads, ponds, hedges). In a broader context, the agricultural landscape contains materials, environments, humans, economies, institutions, and cultural resources [9]. A farmland landscape focuses on the land use system of contiguous farmlands, including the land and its surrounding trenches, hedges, and other components, which have certain ecosystem services 'on site', but indicate spatially broader ecological processes [10]. This property makes the farmland landscape particularly attractive for determining, understanding, and studying the shortand long-term sustainability trends of the ecology and the economy towards transformative agriculture, balancing the amount of production with the environment. Therefore, compositions and configurations in the matrix of farmland are the key factors determining the biodiversity and ecosystem services [11,12], and the role of cropping systems is particularly important.

Spatial heterogeneity is increasingly being considered in crop layout research globally [13]. The crop layout theory focuses on the agricultural plant species and their proportion and distribution in farmlands within a farm or a region, to not only increase resource use efficiency and the capacity for and potential of sustainable development but also adapt to the local climate, market, and nutrient demands of residents $[13,14]$.

The patch-corridor-matrix model and the crop layout theory complement each other when studying farmland heterogeneity. They both focus on spatial and temporal heterogeneity and can be used at basic scales of composition and configuration. The patchcorridor-matrix model describes a landscape's spatial heterogeneity, i.e., interactions and the relationship of farmland landscape compositions and configurations. The crop layout theory clarifies crop production input and output benefits, crop climate adaptations, response abilities, and layout principles on farmland and larger scales. Thus, the two theories have a huge amount of potential in the research on farmland landscapes. Landscape heterogeneity comprises compositional and configurational heterogeneity. Compositional heterogeneity refers to different land surfaces present in the farmland landscape (land cover and its spatial abundance), while configurational heterogeneity represents the complex patterns of space allocation for different compositions [8] (distribution form and spatial arrangement). Farmland landscapes are diverse and highly heterogeneous due to the presence of natural and artificial resources, cropping systems, cultivation measures, and farming practices.

The problem of agriculture nowadays requires a scientifically sound and environmentally adaptable 'arrangement' of composition and configuration from a landscape perspective in order to balance ecosystem service trade-offs and improve resource use efficiency, which ultimately provides the theoretical basis for sustainable development $[8,12,15]$. Yet, the adoption of this approach in practice remains hampered overall for both large-and especially small-hold-farmers, the main force of agricultural production worldwide, due to economic and resource constraints [4,15]. Therefore, a great deal of potential exists in improving the agricultural landscape heterogeneity, i.e., composition and configuration, and, hence, ecosystem services. However, the role and the relationships between the structure of and ecosystem services in landscapes of farmland remain unclear [16,17]. As with many growing areas of research, there is the risk of hindering the cross-study synthesis of results due to the lack of consistency in conceptualization and terminology among studies and disciplines. The main objectives of this review are threefold. Firstly, this paper (i) describes the relationships/connections between compositional and configurational heterogeneity, as well as the resulting ecosystem services (Sections 3 and 4). Such a description is valid for the future redesign of farmland landscapes to achieve green and sustainable agriculture development. Based on the proposed description, the paper then (ii) refines and improves the existing knowledge about the farmland landscape in order 
to build a theoretical framework (Section 5), which combines the patch-corridor-matrix model of landscape ecology and the crop layout theory of farming systems as the entry point to research farmland instead of the ecosystem at the field scale typically studied by other studies. Finally, this paper (iii) critically reviews the mutually influenced and interconnected composition, structure, and ecosystem services of farmland landscapes, reveals the current status and difficulties, and, thereby, proposes future research avenues (Section 6). The ecosystem services in agricultural landscapes and their governance have previously been critically reviewed in an eco-societal context [18] and the present review further elaborates in detail the biophysical structure of the farmland landscape and the ecosystem services within.

\section{Materials and Methods}

\subsection{Overall Design and Selection of Papers}

This study adopted an integrative and concept-centric qualitative approach based on the existing literature, including different theories and principles, to construct or reconceptualize a novel body of scientific knowledge in the form of a framework, models, theories, and hypotheses following a logical reasoning procedure $[19,20]$. This approach is suitable for integrative theoretical research as it comprehensively analyzes insights from the published literature and sets a theoretical basis for future research [21]. Therefore, given the scope of this study, the review concentrated on studies encompassing compositions, configurations, and ecosystem services of cropping systems and farmland landscapes. Research and review articles published in English were selected under a search set in the Web of Science (https: / / apps.webofknowledge.com/ (accessed on 7 January 2021) based on topics $(\mathrm{TS})=\left(\mathrm{farm} *\right.$ landscape ${ }^{*}$ or heterogeneity) and research area $(\mathrm{SU})=($ agriculture $)$ not research area $(\mathrm{SU})=$ (public administration or urban studies or entomology or forestry or business economics or zoology or marine biology or sociology or horticulture) and year published $(\mathrm{PY})=(2000-2020)$. These criteria yielded 7484 papers. Abstracts of the initially selected papers were screened, and 1923 publications were selected with a focus on crop diversity (different cropping systems such as monocropping, intercropping, rotation, and strip cropping). We further filtered the selected 239 publications with a focus on ecosystem services (e.g., productivity, pollination, and insect control). Full-text reading was conducted thereafter and after filtering those articles with answers to the same or similar questions to avoid the duplication of content, 91 papers were finally selected. The framework itself, as well as tables and diagrams, were refined under a combination of narrative and visualization techniques in order to analyze and synthesize the existing knowledge based on the patch-corridor-matrix model and the crop layout theory by listing it in a concept matrix containing a categorization of different themes (composition and its subsections; configuration and its subsections). Ultimately, the current research status and difficulties, as well as future research avenues, were determined.

\subsection{Analysis, Synthesis, and Reconceptualization Methods}

The concept of this review employs the patch-corridor-matrix model and the crop layout theory and primarily contains the topics of composition proportion, distribution shape, and spatial arrangement. The selected papers were classified based on their topics and documented relationships were critically analyzed by the logical reasoning method through reading abstracts and full-texts. The composition category, ecosystem services, and relationships of each composition were critically categorized and summarized. This helped us combine the patch-corridor-matrix model and the crop layout theory together into an integrated novel framework when specific studies were discussed and analyzed in the context of these two theories. The summarized relationships, the theoretical synthesis, and the framework were gathered into mind maps, flow charts, and concept figures. Furthermore, problems and potential solutions to problems in current farmland landscape research identified in the critical analysis are listed in a table to clarify future research topics in order to fill the gap newly revealed by using the novel framework. Finally, the same 
rationalist method was also used to specify and explain the impacts of field management, research methods and spatio-temporal analyses, and scaling issues to provide a foundation for future researchers of farmland landscape heterogeneity and its ecosystem services.

\section{Compositional Heterogeneity Influences Ecosystem Services}

\subsection{Vegetation Heterogeneity}

Vegetation diversity enhances the stability of the farmland ecosystem, e.g., by contributing to crop yield stability [22]. Improving the non-crop diversity promotes the quality of the biological habitats and provides shelter for different animals in the farmland (Figure 1). It also controls soil erosion and non-point sources of pollution, improving the farmland's microclimate and aesthetics [23]. Previous studies reported negative impacts on up to $50 \%$ of ecosystem services in simplified farmland landscapes with a loss of biodiversity and crop yield [24]. Additionally, it should be noted that, despite an increase in species richness by an increase in compositional heterogeneity, surpassing the optimal level can result in habitat fragmentation and actual species loss [25].

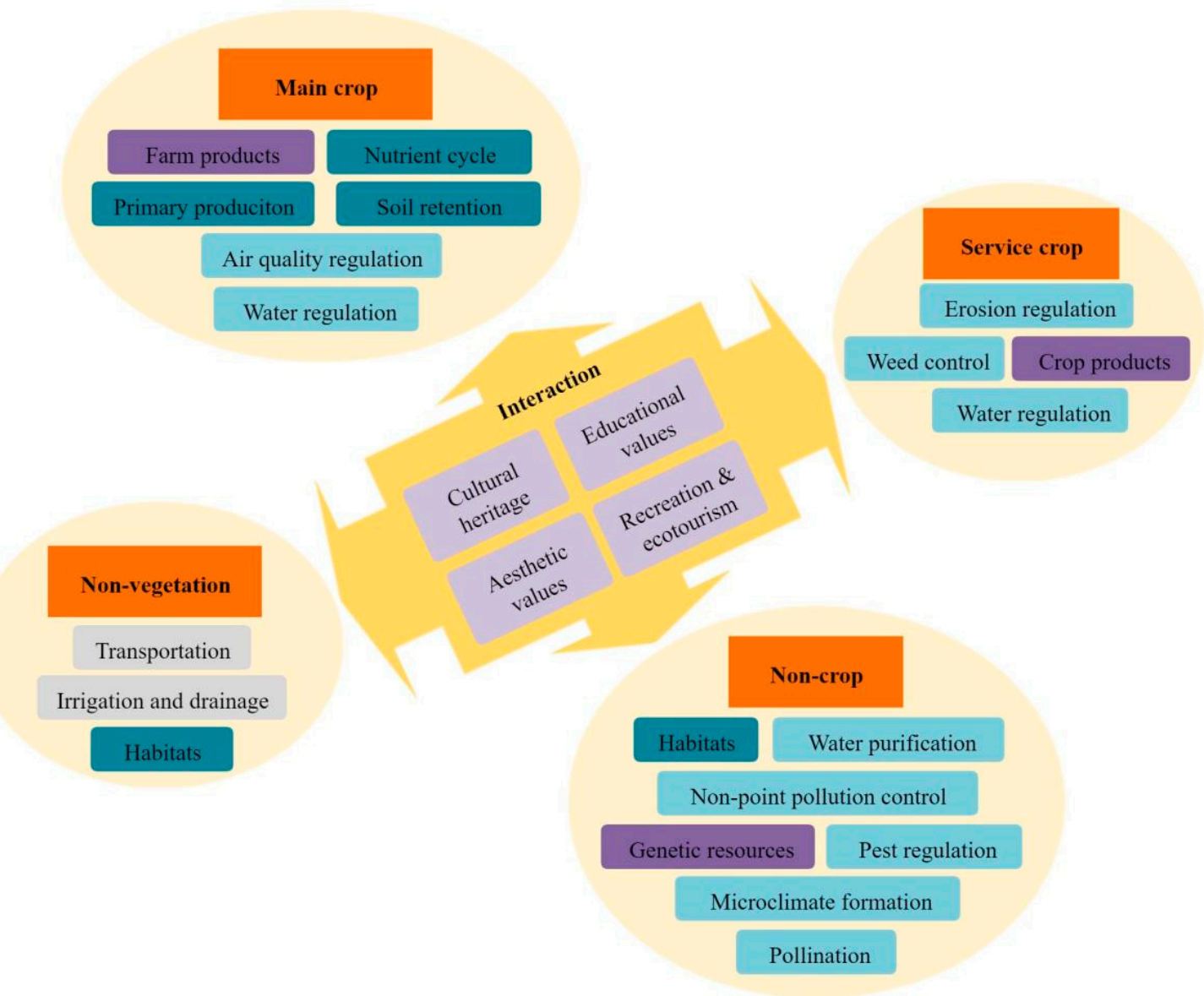

Figure 1. Interactions between farmland landscape compositions and their ecosystem services. Purple rounded rectangles represent final services comprising provision (dark purple) and cultural (light purple) services. Blue rounded rectangles represent supporting (dark blue) and regulation (light blue) services. Gray rounded rectangles represent shapes providing support for different functional populations. Cultural services usually function in interactions between the compositions of the farmland landscape. 


\subsubsection{Crop Heterogeneity}

The main crop is the most important aspect of the vegetation heterogeneity and is grown for food, feed, or fuel with the primary purpose of economic benefits for the farmer and a contribution to the majority of the provision services (Figure 1). Main crops, such as wheat, corn, and rice, form the dominant population in the farmland landscape. The cover crop, which is a well-known service crop, aims to provide additional benefits to either the main crop or the farmland landscape as a whole, improve the crop yield, soil quality, and nutrient utilization [26-28], reduce and suppress weed growth [29], and ultimately improve the farmland's ecological environment [30]. A catch crop is a cover crop grown outside of the main crop season in order to capture soil available nutrients that would otherwise leach out of the root zone, thus comprising an important element for maintaining the sustainable development of the farmland landscape [27,30]. Studies have shown that both legume and non-legume catch crops can effectively reduce nitrogen leaching [31]. Green manures are specific plant species grown to improve the overall soil quality (nutritional status, organic matter) by either being cut and plowed into the soil or simply being left on the soil surface for an extended period of time prior to tillage.

Increasing the crop diversity benefits the ecological functions of the farmland landscape through maintaining and improving the soil fertility and accelerating nutrient cycling (Figure 1). For example, grain-legume intercropping increases nitrogen and phosphorus uptake by the grain crops and enhances iron absorption by the legume [32]. Alongside increased crop diversity, intercropping also increases the resource use efficiency [27,33] and regulates the rhizosphere's temperature and humidity [34]. Isbell et al. [35] showed that diverse crop species and varieties, which occupy different spatio-temporal niches in the farmland landscape, increase crop yield. Long-term planting of a single species/variety, i.e., monocropping, on a large area is known to reduce the farmland's genetic diversity and the ecosystem stability, leading to a large reduction in predators [36]. Despite the crop diversity introduced by intercropping, the effect of mixed cropping and other diversification patterns on various services in the farmland landscape remains inconsistent overall (e.g., [37]). There are benefits to disease and pest resistance with effects on pests and predators and their mechanisms largely determined by the biological characteristics and behavioral responses of all involved crops [36,38]. Additionally, the secretions of corn, wheat, and sunflower crops can inhibit pathogen microorganisms and prevent pest development, thereby providing other beneficial organisms such as insects with nectar and other foods to increase diversity $[39,40]$. Moreover, crop heterogeneity consists of different crop species and varieties [38] and the failure of one crop due to, e.g., unfavorable weather conditions or a pest attack can be 'compensated for' to an extent by another crop [36].

\subsubsection{Non-Crop Heterogeneity}

The number of studies on the structure and the function of non-crop heterogeneity in farmland landscapes has been increasing during the last few years, as non-crop vegetation and its diversity are being recognized to play a major role in promoting the supporting, regulating, and cultural services of the entire ecosystem [41] (Figure 1). Heterogeneous noncrop structures, which persist for a longer time (for instance, old hedges), may conserve biodiversity and even protect endangered species [42]. Therefore, hedges and farmland windbreaks can be used for soil fixation, wind protection, and improved landscape connectivity, thereby promoting the formation of a microclimate and corridors for animals and plants to move throughout the entire farmland landscape [23].

Schulte et al. [43] reported that $10 \%$ grass strips instead of crops in a farmland landscape not only has the lowest impact on crop yield, but also increases the numbers of insects, pollinators, and birds and reduces water runoff and soil and phosphorus loss. In addition to their high aesthetic value, flower strips set according to insect feeding habits can significantly decrease the number of aphids in potato and leaf beetles in winter wheat, with a positive effect on pest control that might even reduce pesticide use [35,44]. In addition, planting a certain proportion of grass in strips on the field can simultaneously increase the 
number of pollinators and birds, reduce water runoff and phosphorus loss, and ensure crop yields [40]. Farmland borders and hedges accommodate many species, especially those highly dependent on semi-natural habitats, such as birds, wild bees, aphids, and yellow peaks, which also reduce pests in adjacent farmlands. Flowering plants are of particular importance as they provide important habitats to pollinators, including bees, butterflies, and moths [45]. Perennial grass and vegetation litter increase the diversity of arthropods and provide food resources and nests for birds [46]. Previous studies show that the presence of woodland or grassland adjacent to farmland has a large influence on the species richness and the populations of small animals, butterflies, and birds [47,48].

\subsection{Non-Vegetation Heterogeneity}

Local roads connect fields and enable the transportation of goods and the movement of people and machinery in the field $[47,48]$ (Figure 1). At the same time, roads are the 'transport channels' for (micro)organisms and seeds carried by agricultural machinery and other tools. Naturally occurring streams and ponds, as well as manmade ditches, are used for irrigation and drainage in the field, providing both water conservation and habitats for animals and plants $[49,50]$. An improperly constructed or unmaintained manmade composition greatly affects the farmland landscape's functions. For instance, while concrete and asphalt roads are artificial and lack water permeability [51], field roads, which are usually made of soil, sand, and gravel, support side vegetation growth and insect dynamics [51]. Stone ditches are uneven and their surface is conducive to mosses, fish, and larvae, whereas concrete canals are suitable for areas with extremely poor soil conditions and large irrigation and drainage needs [49,50]. Hardened buildings and ruins in the farmland, including telegraph poles, abandoned old factories present in some agricultural landscapes, and storage ponds, form relatively safe and stable habitats for many amphibians, birds, and plants [42].

\subsection{Composition Proportion}

There are different compositions in the farmland landscape and their area proportions account for different ecosystem services and values (Figure 2). For instance, crop yield, animal diversity, and weed diversity are largely influenced by the plant species in the farmland landscape. Animal diversity increases with an increasing proportion of natural or semi-natural habitats [8,52], which in turn increases the natural enemies of pests and thus pests' mortality [53]. Maintaining at least $5 \%$ of natural habitat on a farm can effectively maintain biodiversity [54]. In grassland ecosystems, higher species diversity by, e.g., sowing a mixture of grass or grass-clover species may also increase forage production [55]. Yet, few studies focus on the proportion and the ecological function of each composition in the farmland ecosystem. Pywell et al. [22] found that $3 \%$ and $8 \%$ of natural and semi-natural habitat, respectively, under the same management on a farm increased crop yield after four years. Studies under European conditions showed that high crop diversity at the edges of farmlands was partly responsible for increased production, and $10-20 \%$ of semi-natural habitat on farms showed a higher yield, while less than $40 \%$ of arable land had the lowest yield [37]. 


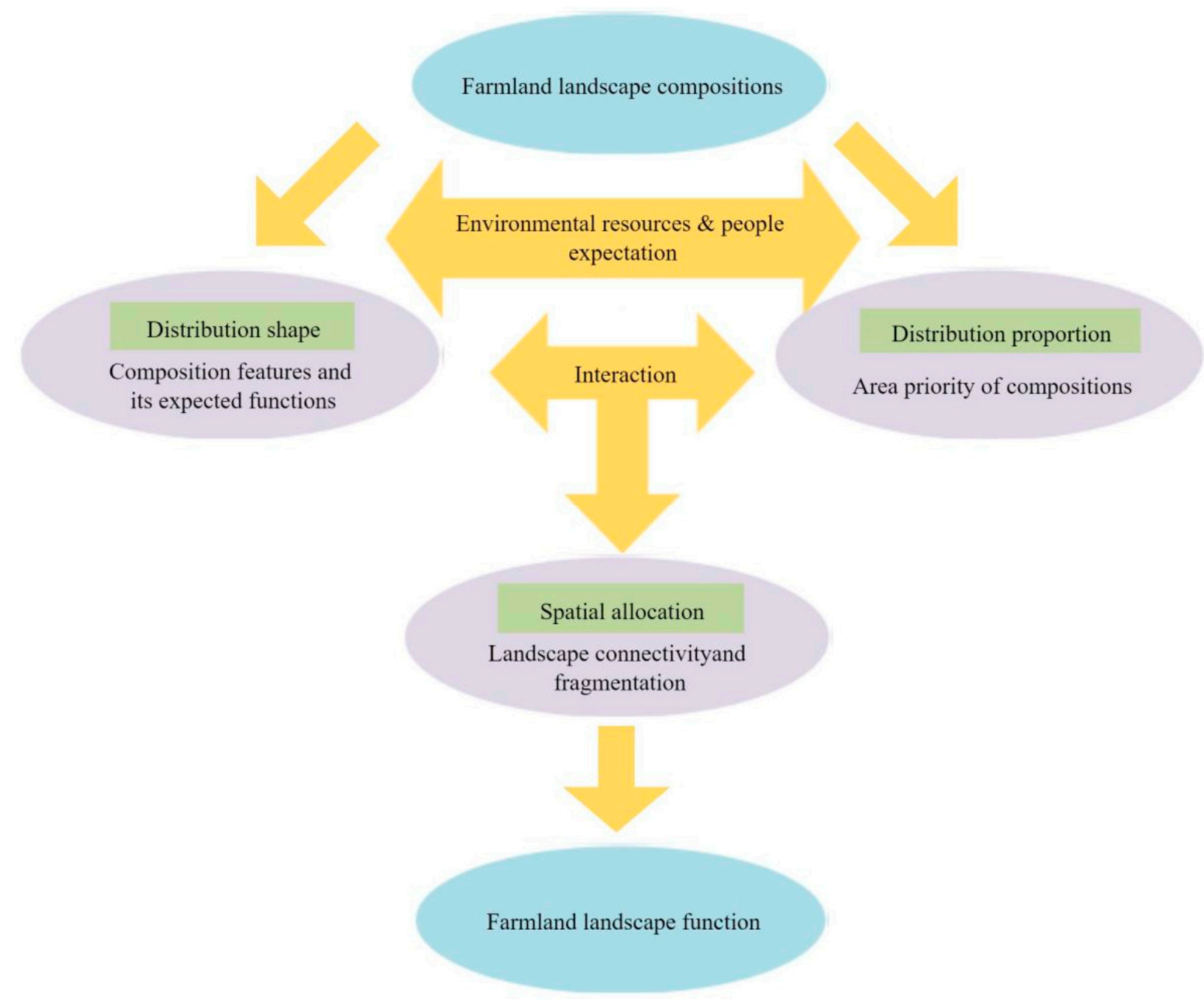

Figure 2. Overview of farmland landscape configurations. Compositions, environmental resources, and people's expectations influence the distribution shape and proportion, while their interaction ultimately establishes the spatial arrangement of the compositions and the function.

\section{Configurational Heterogeneity Influences Ecosystem Services}

\subsection{Distribution Shapes}

There are several distribution shapes in the farmland landscape. Patches occupy the main and the largest area, thereby supporting critical provision services, whereas strips and points occupy smaller areas based on composition features and their expected function (Figure 2). Small natural features (SNFs) have attracted attention over the years as they usually appear as strips and points but have a larger ecological effect than the size of their area reflects [42,56]. For instance, at certain times SNFs can limit larger-scale ecological processes and at other times support biodiversity, species abundance, and crop productivity [56]. Generally, SNFs are of natural origin or manmade with natural materials and exist in fixed locations for a long time. Typical SNFs in farmland landscapes include various strips, such as farmland boundaries, hedges, aisles, and riverbanks, points containing large old trees randomly distributed in farmland landscapes, residues/objects from previous and current farmland landscape use (succession or interference residues), small ponds, burial heads, and other point-like structures [42]. 


\subsubsection{Patches}

In any given farmland landscape, a larger marginal effect results in larger mosaics; therefore, decreasing mosaics can decrease the patch density as well as the area of marginal effect. There are two important patch strategies that emphasize the land use change of crops and semi-natural habitats. The first is land sharing, which is based on land use by integrating crop production and biodiversity on the same land and reducing external chemical inputs and preserving natural habitat patches in the farmland (Figure 2). Land sharing has, therefore, high habitat heterogeneity and can help to maintain higher biodiversity $[57,58]$ by employing organic cultivation methods and promoting pollination and biological pest control [59]. The second patch strategy is land sparing, which combines lands for intensive agricultural production and for natural habitats and ecosystem conservation, such as nature reserves, ecological control, and rotational farming $[57,58,60]$. The ecological effects of land sharing and land sparing are different, and the choice of strategy requires consideration of local factors such as the farmland landscape's structure and background and the presence of species [58]. Previous studies have shown that land sparing should be adopted when food provisions are higher than other services, despite the limitations to the ecological functional distance of non-productive composition, whereas land sharing is suitable when food provisions are lower than other services [61,62]. Since land sharing requires more land to achieve the same purpose, the overall footprint of patches under land sparing is smaller $[62,63]$. The integration of large and small patches to form a diverse landscape and increase spatial connectivity is an effective strategy for protecting biodiversity [59].

\subsubsection{Strips}

Strips enhance the landscape connectivity of farmland landscapes, making it easier for flora and fauna to distribute. Common strips include hedges, shelterbelts, flower and grass strips, roads, ditches, and farmland boundaries. The area ratio of the marginal effect of strips is large and thus often cannot retain the same species for a long time [64]. Strips offer habitats for birds and insects to forage, nest, and avoid natural enemies [42] and, at the same time, help to intercept water and nutrients and reduce soil erosion. Compared with farmland, other strips containing riparian corridors, hedges, irrigation and drainage systems, etc. provide support for different functional populations and local plant species [41] and promote species connectivity [56]. Previous studies reported a reduction in pests due to the presence of edges, which increase the mortality of crop pests, for example in rapeseed [53] and winter wheat [65]. The longer the total length of the strips, the greater the biodiversity in the farmland landscape. For instance, a study on German farmland landscapes found that after land consolidation, the total length of hedges had significantly reduced, with a concomitant reduction in the vegetation diversity [42].

\subsubsection{Points}

Points are scattered spots in farmland landscapes that usually occupy a small area and have a rather strong ecological function. The compositions that appear as points are mainly non-crop or non-vegetation compositions, such as large old trees, utility poles, and water wells. A certain number of points promotes ecosystem biodiversity and provides soil, water, habitats, and nutrients [42]. Large old trees are typical point compositions and important structures in farmland ecosystems with rich ecosystem services [66]. The treetop is a habitat for birds, the middle part provides dwelling places for field mice and insects, and the lower canopy and the trunk provide nutrients for lichens, moss, and parasitic plants. Tall canopies can intercept sunlight energy to convert solar energy into biomass and provide nectar sources for pollinators and shade for small trees and animals. At the same time, the extensively developed root system helps to maintain the soil and water status and promotes nutrient cycling [66]. 


\subsection{Spatial Arrangement}

The spatial arrangement of the various compositions and structures in the farmland landscape affects the landscape's connectivity and fragmentation (Figure 2). The connectivity of non-crop areas in farmland landscapes influences the migration capacity of the biome, which impacts many important regulating services, such as pollination, pest control, seed transmission, disease regulation [67], and diversity persistence [68]. The fragmentation of non-crop areas includes a decrease in the number of habitats and their patch sizes and an increase in the number of habitat patches and patch isolation [69]. Studies have suggested that landscapes with a high density of patches (i.e., their boundaries) have more pollination than those with a low patch boundary density $[67,70]$. Moreover, the above- and belowground components of the vegetation interact with each farmland landscape composition directly or indirectly, and the effective distance is limited, thus affecting the degree of fragmentation. For example, different row ratios of corn and soybean in an intercropping system would have different impacts on their yield and the presence of trees can decrease crop yields due to the competitive advantage for resource uptake, which nevertheless lessens with an increase in distance [39]. In sloped farmland landscapes, setting buffer zones can effectively reduce the loss of soil water and nutrients.

\section{Framework of Farmland Landscape Heterogeneity}

\subsection{Layout of the Farmland Landscape}

The heterogeneity of the farmland landscape determines the layout of the farmland, which affects the flows of matter and energy in the production system and confers different values on the farmland, i.e., attributes, services, and aesthetics [71]. The compositional heterogeneity consists of different compositions and their amounts, and compositions comprise vegetation compositions and non-vegetation compositions (Figure 3). The amount of a composition defines the population amount, such as the crop area and its proportion. Non-vegetation compositions include land surfaces such as field roads and ditches, natural or semi-natural streams and ponds, wells, and communication poles, i.e., facilities necessary for sound agricultural production and an appropriate living standard, but also for maintaining and improving the farmland landscape's function. The vegetation composition is one of the main factors affecting the farmland landscape's structure [72] and includes crop and non-crop types. The former are further divided into main and service crops. Main crops are distributed over a larger area and have crucial impacts on the agro-ecological ecosystem services, such as wheat in wheat fields, rice in paddy fields, and cotton in cotton fields. Service crops are grown temporally and spatially during or after the growth of the main crops and provide ecosystem services whose impacts are often greater than those of harvested crops [72], such as improving the soil fertility by legumes (a service crop) intercropped with corn (a main crop) [73] or reducing nutrient losses after the harvest of the main crop [31]. The same crop can have both main and service functions, but in different farmland landscapes. Non-crop types include vegetation in the farmland landscape other than crops, such as non-crop grasses, shrubs and trees, wildflower strips, and scattered semi-natural or economic forests, all of which play an important role in regulating water and nutrient allocation and use as well as farmland aesthetics.

The configurational heterogeneity is a complex characteristic of the farmland landscape that reflects the spatial layout of each composition, i.e., the shape and the spatial arrangement (Figure 3), as well as the connectivity and the fragmentation as a whole. The distribution shape refers to the presented shape of a composition, whereas the spatial arrangement is the relative position of the composition and the structure [74]. All compositions can be distributed into patches, especially when the main crops occupy a continuous and large area of the farmland landscape. Strips are special patches and almost all compositions can be put into strips. Compared with patches, strips generally occupy a smaller area and include non-crop and non-vegetation species, such as hedges, roads, and ditches. Non-crop and non-vegetation species can comprise compositions displayed 
as points, such as a big tree or a water well, with ecosystem services often related to their duration of existence in the farmland landscape.

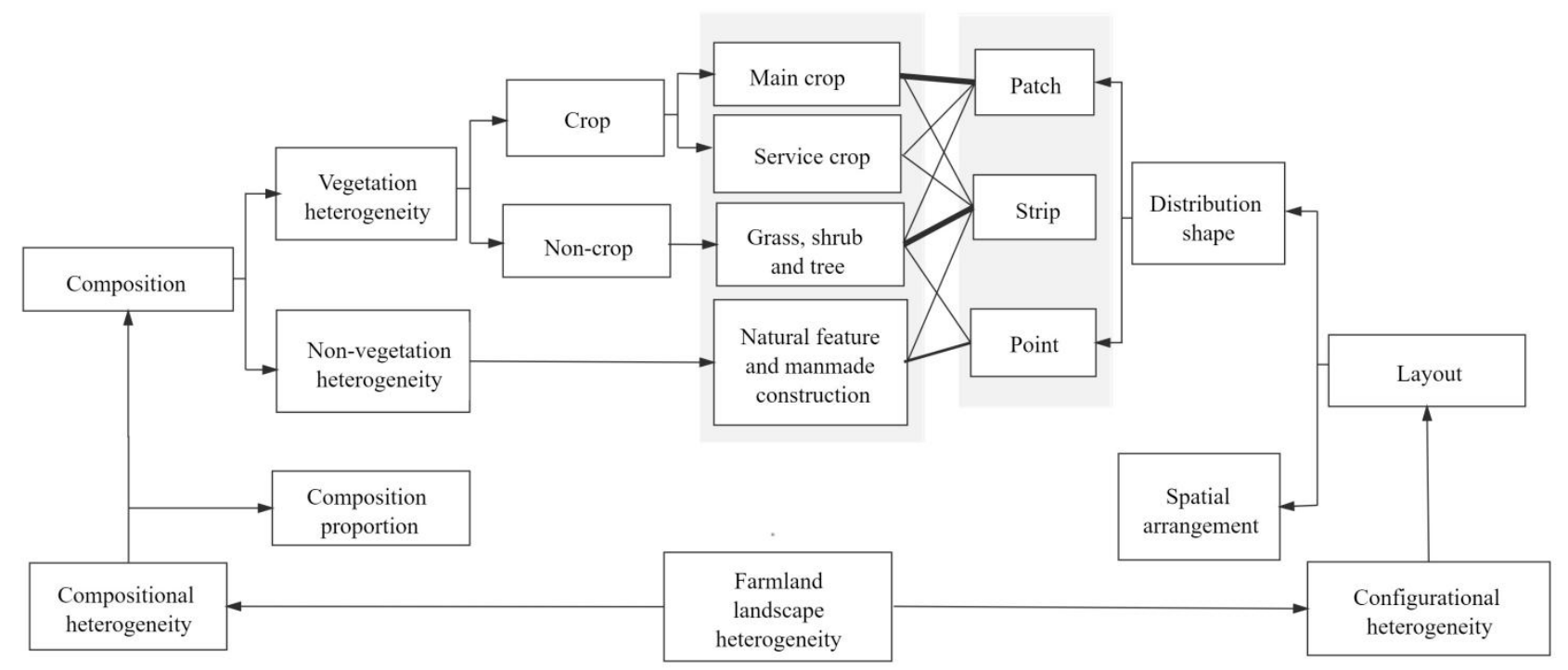

Figure 3. Framework of farmland landscape heterogeneity and relations between the components of the compositional and configurational heterogeneity. Thicker lines indicate a stronger connection between compositional (what and how many) and configurational (shape and spatial arrangement) heterogeneity (shaded gray).

\subsection{Ecosystem Services of the Farmland Landscape}

The spatial heterogeneity of the farmland landscape affects ecological processes and ecosystem services, thereby producing a vast variety of ecosystem services [8] (Figure 4). The ecosystem services comprise supporting, regulating, provisioning, and cultural services, which can be quantitatively compared through units of currency and energy [75,76]. The supporting and the regulating services emphasize processes closely affecting the environmental outputs of the ecosystems, whereas the provisioning and the cultural services emphasize results, i.e., products and benefits that people obtain from the ecosystems [77]. For instance, an abundance of biodiversity is embedded in high compositional and configurational heterogeneity, which results in a greater abundance of supporting, regulating, and cultural services [78]. It should be mentioned that low-value services could limit the ecosystem services of the whole ecosystem, which are driven by high-value services [79]. For instance, the demand for high crop yields may result in the recognition and valuation of provisioning services and a reduction in the value of the other services [80]. Although intensive agricultural systems composed of monocultures are highly dependent on supporting and regulating services, which minimize or even close the yield gaps, they typically reduce the soil services provided by organic matter and the farmland landscape's heterogeneity due to a reduced vegetation heterogeneity and increased human interference $[78,79]$. Residue retention and the diversification of cropping systems and rotations, on the other hand, are known to result in the maintenance of or an improvement in soil services [79,81,82]. In addition, previous studies show that complex landscapes increase the ecosystem diversity, increase the richness and density of both flora and fauna, and improve the biological control of pests and diseases through protecting natural and resource-rich habitats and direct rotation with diverse crops [83]. Moreover, complex heterogeneity enhances the farmland ecosystem's resilience to disturbances [52]. Therefore, complexity is a desirable property of a farmland landscape. In contrast, large fields cropped with monocultures or 'simple' crop rotations without non-crops generally reduce diversity $[84,85]$ and crop yields (e.g., [82,86]) due to the increased incidence of pests and diseases and the reduced soil fertility and resource use efficiency $[82,86]$. 


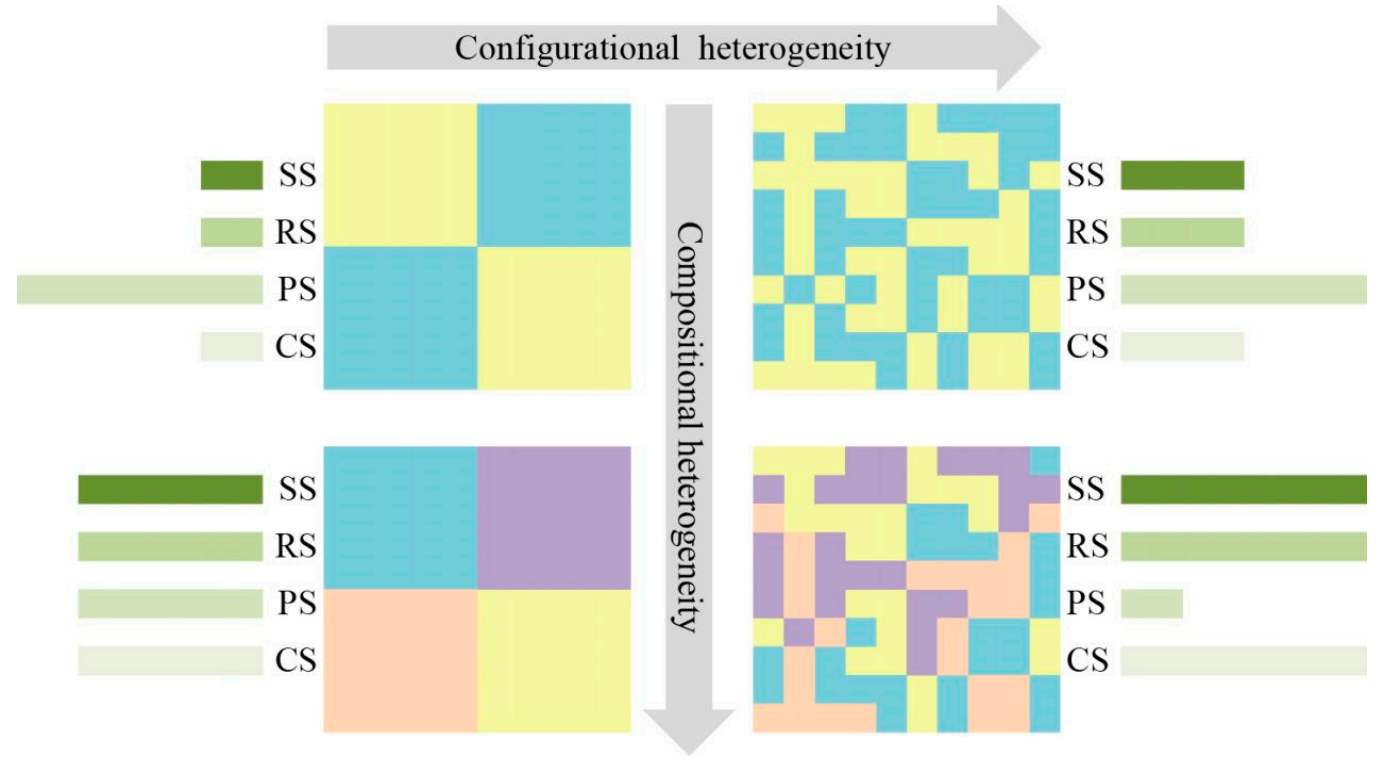

Figure 4. Relationships between the heterogeneity and the ecosystem services of a farmland landscape. Configurational heterogeneity increases from left to right and compositional heterogeneity increases from top to bottom. The colors of the squares represent different compositions, such as crops and non-crops. The length of the bars indicates the size of supporting (SS), regulating (RS), provisioning (PS), and cultural (CS) services.

\section{Current Status of and Prospects for Research on Farmland Landscape Heterogeneity}

\subsection{Problems and Proposed Solutions in Current Farmland Landscape Research}

Farmland landscape research has been conducted for the past several decades, especially regarding the relationships between diversities of vegetation and pests and natural enemies at the landscape scale $[74,87]$. However, challenges remain at both the field scale and the landscape scale (Table 1). The cropping system, such as long-term continuous monocropping, is a common problem in farmland landscapes. Diversification through rotation, inter-, and strip cropping is a well-established method by which to challenge and potentially alleviate issues arising from monocropping, though a locally suitable cropping system needs to be verified [88]. External chemical inputs, soil and land deterioration and pollution, and a lack of biodiversity can be seen at both the field scale and the landscape scale. These "threats" can move during the crop growing season or be allocated anywhere on the farmland, which makes it possible for them to have an influence from the field to the landscape scale. Diversified measures can be executed to settle these problems, from tillage measures, cropping systems, and material and human input regulation to landscape compositions and configuration arrangements. In fact, a poor-quality farmland landscape is a mismatch among landscape compositions and their ecosystem services. Sustainable intensification has also attracted attention regarding the balancing of environmental sustainability and agricultural production $[33,89]$. Redesigning the farmland landscape is an important tool for improving the farmland landscape and achieving sustainable intensification, which considers resource use efficiency and the complementarity of technological and agronomic measures $[78,90]$. In order to optimally redesign farmland landscapes by selecting suitable compositions and configurations to balance provisioning services and the environmental burden, there is a need for better ecological assessment of spatial heterogeneity [41] and agronomic measures. However, farmland landscapes differ in their functions and limitations between regions due to differences in the microclimate, topography, resources, and farming practices. Considering that crop adaptability and food requirements are also different, the scientific redesign of different farmland landscapes is required. Therefore, the interactions between the composition and the configuration of the farmland landscape, the ecological effects of different cropping systems, especially diversified cropping systems, and farming measures need to be further researched. 
Table 1. Problems and proposed solutions in current farmland landscape research listed from the perspective of ecosystem services of natural and semi-natural resources, chemical inputs, and crop, non-crop, and non-vegetation compositions.

\begin{tabular}{|c|c|c|c|c|}
\hline Problems & Unit (Field or Landscape) & Proposed Solutions & Possibility to Cross-Scale ${ }^{a}$ & References \\
\hline $\begin{array}{l}\text { Single cropping, long-term } \\
\text { monocropping }\end{array}$ & Field & $\begin{array}{l}\text { Rotation; intercropping; strip } \\
\text { cropping }\end{array}$ & + & {$[24,88]$} \\
\hline $\begin{array}{l}\text { A large input of chemical } \\
\text { fertilizer and pesticide, } \\
\text { Low resource use } \\
\text { efficiency }\end{array}$ & $\begin{array}{c}\text { Field } \\
\text { Landscape }\end{array}$ & $\begin{array}{l}\text { Reduce or replace chemical } \\
\text { fertilizers and pesticides; } \\
\text { conservation irrigation; good } \\
\text { agricultural practices; integrated pest } \\
\text { management; semi-natural habitats }\end{array}$ & +++ & {$[45,61]$} \\
\hline $\begin{array}{c}\text { Soil deterioration, land } \\
\text { degradation }\end{array}$ & $\begin{array}{c}\text { Field } \\
\text { Landscape }\end{array}$ & $\begin{array}{l}\text { Conservation tillage; cereal-legume } \\
\text { rotation; use of organic fertilizers } \\
\text { and green manure; land restoration; } \\
\text { buffer zone }\end{array}$ & +++ & {$[33,46]$} \\
\hline $\begin{array}{l}\text { Soil erosion, non-point } \\
\text { pollution }\end{array}$ & $\begin{array}{c}\text { Field } \\
\text { Landscape }\end{array}$ & $\begin{array}{l}\text { Conservation tillage; ecological } \\
\text { interception and buffer zone; } \\
\text { reduction of chemical fertilizers and } \\
\text { pesticides }\end{array}$ & ++ & {$[42,76]$} \\
\hline $\begin{array}{l}\text { Poor-quality farmland } \\
\text { landscape }\end{array}$ & Landscape & $\begin{array}{c}\text { Integrated landscape management; } \\
\text { land-use planning; semi-natural } \\
\text { habitat protection }\end{array}$ & + & {$[59,72]$} \\
\hline Lack of biodiversity & $\begin{array}{c}\text { Field } \\
\text { Landscape }\end{array}$ & $\begin{array}{l}\text { Diversified cropping (agro-forestry, } \\
\text { diversified cultivars, crops, and } \\
\text { cropping systems); protection of } \\
\text { important biological habitats around } \\
\text { the farmland; ecological restoration; } \\
\text { semi-natural habitats }\end{array}$ & +++ & {$[40,43]$} \\
\hline $\begin{array}{l}\text { Mismatch among } \\
\text { ecosystem services of the } \\
\text { farmland landscape, } \\
\text { mismatch in crop and } \\
\text { non-crop compositions }\end{array}$ & Landscape & $\begin{array}{l}\text { Redesign of the crop planting system; } \\
\text { redesign of the farmland landscape }\end{array}$ & + & {$[30,78,90]$} \\
\hline
\end{tabular}

a The number of + symbols (from 1 to 3 ) denotes few to many.

\subsection{Impacts of Field Management}

Field management influences the ecosystem services within the farmland landscape and current research mostly focuses on the effects on crop yield and supporting/regulating services, whereas integrative impacts on ecosystem services and compositions are neither clearly defined nor sufficiently researched. The use of high-quality seeds and improved cultivation and farming techniques has become the key factor in high crop yields, whereas no tillage increases the soil organic carbon, which in turn positively affects biological and weed control [91] and crop yields [92]. Deep subsoiling, i.e., ploughing deeper into the subsoil, can loosen and aerate the root zone and support root development and water and nutrient uptake and retention, which also increase crop yields. Adopting suitable irrigation methods and moderate (e.g., deficit) irrigation has the potential to maintain crop yields and improve water use efficiency. Water-saving irrigation can improve the sustainability of regional water resources given no change in a cultivated area [93]. Compared with no addition, the application of fertilizers has increased food production for the past several decades by at least 30\% [94]. However, the global greenhouse gas emissions due to the production, transport, and application of fertilizers account for about $2.5 \%$ of the total greenhouse gas emissions [95]. In the highly populated and fast-developing countries, such as China and India, agricultural emissions of nitrogen and phosphorus account for more than half of their total emissions [96]. Agricultural mechanization can be used to carry out precise land preparation, sowing, fertilizer and pesticide application, irrigation, and harvesting operations, which can improve the resource use efficiency of water, fertilizers, and medicines, promote crop growth, increase crop yield, and enhance the sustainability of agricultural resources and the environment [97]. 


\subsection{Farmland Landscape Research Methods}

Farmland landscape research is interdisciplinary and agronomy, ecology, and geography are some of its main disciplines. Though the research methods utilized for studying farmland landscapes are diverse, they can roughly be divided to field trials, spatio-temporal analyses, and literature reviews. In the context of farmland, field experiments require a considerable area for test fields. Pywell et al. [22], in their study on crop yield and pollinator response to non-agricultural compositions, utilized about 900 ha of experimental area. Field experimental studies, therefore, select suitable farmland landscapes and combine sampling and research methods to complete relevant ecological and agronomic experiments $[43,98,99]$. Due to the geographical characteristics of farmland landscapes in terms of size and heterogeneity, analyses of spatio-temporal patterns and changes are of particular interest, and these can be conducted by remote sensing and geographic information systems $[64,99]$. Quantitative studies mostly focus on investigating crop yields and animal and plant diversity in farmland landscapes [37,100,101]. In addition, farmland landscapes have unique ecological and social attributes [102] and biodiversity-based land management practices need to be developed and adopted through the cooperation of all stakeholders and decision-makers [103]. Therefore, researchers need to adopt suitable methods based on the research scale and the specific objective, with a particular focus on spatially orientated analyses in the farmland landscape.

\subsection{Spatio-Temporal Analyses and Scaling Issues}

The circulation of matter and energy requires space-time carriers defined at a certain scale, which remains challenging in landscape-and even more so in farmland landscaperesearch. The time scale largely depends on the problem because of the growth period of vegetation and changes in farming systems, as well as their response time and sensitivity. In general, the longer the time scale, the larger the space required for research [88]. In addition, the spatial scale is related to the problem it represents and for farmland landscape research it varies from $0.05 \mathrm{~km}$ to $6 \mathrm{~km}[99,104,105]$. When the problem consists of a specific measure, such as the sowing amount or time, the no-tillage practice, or the irrigation amount and method, the scale is generally the field as the fundamental unit for evaluating the target performance. However, the comparison of new crop varieties, cropping systems, and patterns requires a larger spatial scale and farm-scale research is common when studying environmental and public policy effects. When discussing land sharing and land sparing, landscape scales are needed for sound analysis and decision-making [99,104,105]. The impact of non-agricultural ratios on the types and numbers of natural enemies and pests also varies with scale. It is worth noting that farmland landscapes and the ecological processes they support are inherently complex systems, in that they have large numbers of heterogeneous components that interact in multiple ways (Figure 4), and exhibit scale dependence, nonlinear dynamics, and emergent properties. The emergent properties of farmland landscapes encompass a broad range of processes, such as pest and disease control and biogeochemical cycling, which influence biodiversity and human environments and operate at scales that are relevant to human societies. An appropriate scale should be therefore carefully selected based on the specific scientific problem. Multi-scale and scaling analyses will contribute to our understanding of farmland landscape heterogeneity and ecosystem service trade-offs and support policy planning and decision-making.

\section{Conclusions}

This review proposed a comprehensive research framework for farmland landscape heterogeneity and ecosystem services. Farmland landscape composition comprises three elements: crop composition (the main crop and the service crop), non-crop composition, and non-vegetation composition. The main crop, usually displayed as large patches with a high large distribution ratio, plays a critical role in provisioning services for food and fiber, while the service crop is important to regulating services. Non-crop and non-vegetation compositions often appear as strips on field margins, with non-crop compositions mainly 
focusing on supporting and regulating services and non-vegetation compositions providing support for farming operations. Both service crops and non-crops significantly regulate the farmland landscape as a whole in coping with negative environmental impacts. There are numerous issues that remain to be resolved in several respects and on different scales, such as the interactions between the composition and the configuration of the farmland landscape, the ecological impact and ecosystem service trade-offs of spatial heterogeneity, and strategies for the adoption of cropping systems and agronomic measures at the landscape scale, which are essential to the evaluation, improvement, and redesign of farmland landscapes.

Author Contributions: Conceptualization, X.W., Y.W. and K.M.; methodology, X.W.; writingoriginal draft preparation, X.W.; writing —review and editing, X.W., K.M. and X.Y.; visualization, M.F.; supervision, F.C.; funding acquisition, F.C. All authors have read and agreed to the published version of the manuscript.

Funding: This research was funded by the National Key Research and Development Program of China, grant number 2016YFD0300200.

Institutional Review Board Statement: Not applicable.

Informed Consent Statement: Not applicable.

Data Availability Statement: Not applicable.

Conflicts of Interest: The authors declare no conflict of interest.

\section{References}

1. Tilman, D. The greening of the green revolution. Nature 1998, 396, 211-212. [CrossRef]

2. Tilman, D.; Cassman, K.G.; Matson, P.A.; Naylor, R.; Polasky, S. Agricultural sustainability and intensive production practices. Nature 2002, 418, 671-677. [CrossRef]

3. Beckmann, M.; Gerstner, K.; Akin Fajiye, M.; Ceaușu, S.; Kambach, S.; Kinlock, N.L.; Phillips, H.R.P.; Verhagen, W.; Gurevitch, J.; Klotz, S.; et al. Conventional land-use intensification reduces species richness and increases production: A global meta-analysis. Glob. Chang. Biol. 2019, 25, 1941-1956. [CrossRef]

4. Pingali, P.L. Green Revolution: Impacts, limits, and the path ahead. Proc. Natl. Acad. Sci. USA 2012, 109, 12302-12308. [CrossRef]

5. Forman, R.T.T.; Godron, M. Landscape Ecology; John Wiley \& Sons: New York, NY, USA, 1986.

6. Mahon, N.; Crute, I.; Simmons, E.; Islam, M.M. Sustainable intensification-“Oxymoron" or "third-way"? A systematic review. Ecol. Indic. 2017, 74, 73-97. [CrossRef]

7. Forman, R.T.T. Some general-principles of landscape and regional ecology. Landsc. Ecol. 1995, 10, 133-142. [CrossRef]

8. Fahrig, L.; Baudry, J.; Brotons, L.; Burel, F.G.; Crist, T.O.; Fuller, R.J.; Sirami, C.; Siriwardena, G.M.; Martin, J.L. Functional landscape heterogeneity and animal biodiversity in agricultural landscapes. Ecol. Lett. 2011, 14, 101-112. [CrossRef] [PubMed]

9. Food and Agricultural Organization (FAO). Landscapes for Life-Approaches to Landscape Management for Sustainable Food and Agriculture. 2017. Available online: http://www.fao.org/3/i8324en/i8324en.pdf (accessed on 8 October 2017).

10. Herzog, F.; Steiner, B.; Bailey, D.; Baudry, J.; Billeter, R.; Bukacek, R.; de Blust, G.; de Cock, R.; Dirksen, J.; Dormann, C.F.; et al. Assessing the intensity of temperate European agriculture at the landscape scale. Eur. J. Agron. 2006, 24, 165-181. [CrossRef]

11. Fried, G.; Petit, S.; Dessaint, F.; Reboud, X. Arable weed decline in Northern France: Crop edges as refugia for weed conservation? Biol. Conserv. 2009, 142, 238-243. [CrossRef]

12. Alignier, A.; Sole-Senan, X.O.; Robleno, I.; Baraibar, B.; Fahrig, L.; Giralt, D.; Gross, N.; Martin, J.; Recasens, J.; Sirami, C.; et al. Configurational crop heterogeneity increases within-field plant diversity. J. Appl. Ecol. 2020, 57, 654-663. [CrossRef]

13. Lu, X.L. Crop layout, land use and land conservation. N. Agric. 1980, 9, 2-3.

14. Beijing Agricultural University. Farming System; China Agriculture Press: Beijing, China, 1981.

15. Li, R.H.; Lin, H.; Niu, H.P.; Chen, Y.Q.; Zhao, S.X.; Fan, L.X. Smallholder preference and agroecosystem service trade-offs: A case study in Xinzheng County, China. Agric. Syst. 2019, 168, 19-26. [CrossRef]

16. Kleijn, D.; Bommarco, R.; Fijen, T.; Garibaldi, L.A.; Potts, S.G.; van der Putten, W.H. Ecological Intensification: Bridging the Gap between Science and Practice. Trends Ecol. Evol. 2019, 34, 154-166. [CrossRef] [PubMed]

17. Weltin, M.; Zasada, I.; Piorr, A.; Debolini, M.; Geniaux, G.; Perez, O.M.; Scherer, L.; Marco, L.T.; Schulp, C. Conceptualising fields of action for sustainable intensification-A systematic literature review and application to regional case studies. Agric. Ecosyst. Environ. 2018, 257, 68-80. [CrossRef]

18. Vialatte, A.; Barnaud, C.; Blanco, J.; Ouin, A.; Choisis, J.; Andrieu, E.; Sheeren, D.; Ladet, S.; Deconchat, M.; Clement, F.; et al. A conceptual framework for the governance of multiple ecosystem services in agricultural landscapes. Landsc. Ecol. 2019, 34, 1653-1673. [CrossRef]

19. Webster, J.; Watson, R.T. Analyzing the past to prepare for the future: Writing a literature review. MIS Quart. 2002, 26, XIII-XXIII. 
20. Torraco, R.J. Writing Integrative Literature Reviews: Using the Past and Present to Explore the Future. Hum. Resour. Dev. Rev. 2016, 15, 404-428. [CrossRef]

21. Ntihinyurwa, P.D.; de Vries, W.T. Farmland fragmentation and defragmentation nexus: Scoping the causes, impacts, and the conditions determining its management decisions. Ecol. Indic. 2020, 119, 106828. [CrossRef]

22. Pywell, R.F.; Heard, M.S.; Woodcock, B.A.; Hinsley, S.; Ridding, L.; Nowakowski, M.; Bullock, J.M. Wildlife-friendly farming increases crop yield: Evidence for ecological intensification. Proc. R. Soc. B Biol. Sci. 2015, 282, 1816. [CrossRef]

23. Yu, Z.; Zhang, Q.; Xiao, H.; Liu, W. Countermeasures of landscape and ecological stewardship in agricultural/rural area of China. Chin. J. Eco-Agric. 2012, 20, 813-818. [CrossRef]

24. Pan, G.X.; Smith, P.; Pan, W.N. The role of soil organic matter in maintaining the productivity and yield stability of cereals in China. Agric. Ecosyst. Environ. 2009, 129, 344-348. [CrossRef]

25. Dainese, M.; Martin, E.A.; Aizen, M.A.; Albrecht, M.; Bartomeus, I.; Bommarco, R.; Carvalheiro, L.G.; Chaplin-Kramer, R.; Gagic, V.; Garibaldi, L.A.; et al. A global synthesis reveals biodiversity-mediated benefits for crop production. Sci. Adv. 2019, 5, eaax012110. [CrossRef] [PubMed]

26. Tonitto, C.; David, M.B.; Drinkwater, L.E. Replacing bare fallows with cover crops in fertilizer-intensive cropping systems: A meta-analysis of crop yield and N dynamics. Agric. Ecosyst. Environ. 2006, 112, 58-72. [CrossRef]

27. Manevski, K.; Borgesen, C.D.; Andersen, M.N.; Kristensen, I.S. Reduced nitrogen leaching by intercropping maize with red fescue on sandy soils in North Europe: A combined field and modeling study. Plant. Soil 2015, 388, 67-85. [CrossRef]

28. De Notaris, C.; Rasmussen, J.; Sorensen, P.; Melander, B.; Olesen, J.E. Manipulating cover crop growth by adjusting sowing time and cereal inter-row spacing to enhance residual nitrogen effects. Field Crop. Res. 2019, 234, 15-25. [CrossRef]

29. Osipitan, O.A.; Dille, A.; Assefa, Y.; Radicetti, E.; Ayeni, A.; Knezevic, S.Z. Impact of Cover Crop Management on Level of Weed Suppression: A Meta-Analysis. Crop. Sci. 2019, 59, 833-842. [CrossRef]

30. Wyland, L.J.; Jackson, L.E.; Chaney, W.E.; Klonsky, K.; Koike, S.T.; Kimple, B. Winter cover crops in a vegetable cropping system: Impacts on nitrate leaching, soil water, crop yield, pests and management costs. Agric. Ecosyst. Environ. 1996, 59, 1-17. [CrossRef]

31. De Notaris, C.; Rasmussen, J.; Sorensen, P.; Olesen, J.E. Nitrogen leaching: A crop rotation perspective on the effect of N surplus, field management and use of catch crops. Agric. Ecosyst. Environ. 2018, 255, 1-11. [CrossRef]

32. Li, L.; Zhang, F.S.; Li, X.L.; Christie, P.; Sun, J.H.; Yang, S.C.; Tang, C.X. Interspecific facilitation of nutrient uptake by intercropped maize and faba bean. Nutr. Cycl. Agroecosys. 2003, 65, 61-71. [CrossRef]

33. Manevski, K.; Laerke, P.E.; Olesen, J.E.; Jorgensen, U. Nitrogen balances of innovative cropping systems for feedstock production to future biorefineries. Sci. Total Environ. 2018, 633, 372-390. [CrossRef]

34. Dong, H.; Li, H.; Huo, C.; Li, A.; Yan, X.; Wang, G.; Zhou, N. Effect Analysis of Cover Crops in Maize/Soybean Intercropping Model. J. Maize Sci. 2019, 27, 95-101.

35. Isbell, F.; Adler, P.R.; Eisenhauer, N.; Fornara, D.; Kimmel, K.; Kremen, C.; Letourneau, D.K.; Liebman, M.; Polley, H.W.; Quijas, S.; et al. Benefits of increasing plant diversity in sustainable agroecosystems. J. Ecol. 2017, 105, 871-879. [CrossRef]

36. Dong, W.; Xu, N.; Xiao, C. The effect of diversified cropping on phytophagous insect behavior. Chin. J. Appl. Entomol. 2013, 50, 1133-1140.

37. Martin, E.A.; Dainese, M.; Clough, Y.; Báldi, A.; Bommarco, R.; Gagic, V.; Garratt, M.P.D.; Holzschuh, A.; Kleijn, D.; Kovács Hostyánszki, A.; et al. The interplay of landscape composition and configuration: New pathways to manage functional biodiversity and agroecosystem services across Europe. Ecol. Lett. 2019, 22, 1083-1094. [CrossRef] [PubMed]

38. Kiaer, L.P.; Skovgaard, I.M.; Ostergard, H. Grain yield increase in cereal variety mixtures: A meta-analysis of field trials. Field Crop. Res. 2009, 114, 361-373. [CrossRef]

39. Su, B.; Chen, S.; Li, Y.; Yang, W. Intercropping enhances the farmland ecosystem services. Acta Ecol. Sin. 2013, 33, 4505-4514.

40. Sun, Y.; Li, X.; Zhang, H.; Chen, B.; Li, Y.; Liu, Y.; Yu, Z. Functions and countermeasures of biodiversity conservation in agricultural landscapes: A review. Chin. J. Eco-Agric. 2017, 25, 993-1001.

41. Smukler, S.M.; Sanchez-Moreno, S.; Fonte, S.J.; Ferris, H.; Klonsky, K.; O’Geen, A.T.; Scow, K.M.; Steenwerth, K.L.; Jackson, L.E. Biodiversity and multiple ecosystem functions in an organic farmscape. Agric. Ecosyst. Environ. 2010, 139, 80-97. [CrossRef]

42. Poschlod, P.; Braun-Reichert, R. Small natural features with large ecological roles in ancient agricultural landscapes of Central Europe-History, value, status, and conservation. Biol. Conserv. 2017, 211, 60-68. [CrossRef]

43. Schulte, L.A.; Niemi, J.; Helmers, M.J.; Liebman, M.; Arbuckle, J.G.; James, D.E.; Kolka, R.K.; O’Neal, M.E.; Tomer, M.D.; Tyndall, J.C.; et al. Prairie strips improve biodiversity and the delivery of multiple ecosystem services from corn-soybean croplands. Proc. Natl. Acad. Sci. USA 2017, 114, 11247-11252. [CrossRef]

44. Tschumi, M.; Albrecht, M.; Entling, M.H.; Jacot, K. High effectiveness of tailored flower strips in reducing pests and crop plant damage. Proc. R. Soc. B Biol. Sci. 2015, 282, 189-196. [CrossRef] [PubMed]

45. Dramstad, W.; Fry, G. Foraging activity of bumblebees (bombus) in relation to flower resources on arable land. Agric. Ecosyst. Environ. 1995, 53, 123-135. [CrossRef]

46. Dennis, P.; Fry, G. Field margins-Can they enhance natural enemy population-densities and general arthropod diversity on farmland. Agric. Ecosyst. Environ. 1992, 40, 95-115. [CrossRef]

47. Duflot, R.; Daniel, H.; Aviron, S.; Alignier, A.; Beaujouan, V.; Burel, F.; Cochard, A.; Ernoult, A.; Pain, G.; Pithon, J.A. Adjacent woodlands rather than habitat connectivity influence grassland plant, carabid and bird assemblages in farmland landscapes. Biodivers. Conserv. 2018, 27, 1925-1942. [CrossRef] 
48. Villemey, A.; van Halder, I.; Ouin, A.; Barbaro, L.; Chenot, J.; Tessier, P.; Calatayud, F.; Martin, H.; Roche, P.; Archaux, F. Mosaic of grasslands and woodlands is more effective than habitat connectivity to conserve butterflies in French farmland. Biol. Conserv. 2015, 191, 206-215. [CrossRef]

49. Needeman, B.A.; Kleinman, P.J.A.; Strock, J.S.; Allen, A.L. Improved management of agricultural drainage ditches for water quality protection: An overview. J. Soil Water Conserv. 2007, 62, 171-178.

50. Ye, Y.; Wu, C.; Yu, J. Ecological design of irrigation and drainage ditches in agricultural land consolidation. Trans. Chin. Soc. Agric. Eng. 2011, 27, 148-153.

51. Ye, Y.; Wu, C.; Yu, J. Ecological design of ditches in agricultural land consolidation: A review. Yingyong Shengtai Xuebao 2011, 22, 1931-1938. [PubMed]

52. Tscharntke, T.; Klein, A.M.; Kruess, A.; Steffan-Dewenter, I.; Thies, C. Landscape perspectives on agricultural intensification and biodiversity-Ecosystem service management. Ecol. Lett. 2005, 8, 857-874. [CrossRef]

53. Thies, C.; Tscharntke, T. Landscape structure and biological control in agroecosystems. Science 1999, 285, 893-895. [CrossRef]

54. Fischer, C.; Thies, C.; Tscharntke, T. Mixed effects of landscape complexity and farming practice on weed seed removal. Perspect. Plant. Ecol. 2011, 13, 297-303. [CrossRef]

55. Rasmussen, J.; Soegaard, K.; Pirhofer-Walzl, K.; Eriksen, J. N2-fixation and residual N effect of four legume species and four companion grass species. Eur. J. Agron. 2012, 36, 66-74. [CrossRef]

56. Hunter, M.L.; Acuna, V.; Bauer, D.M.; Bell, K.P.; Calhoun, A.; Felipe-Lucia, M.R.; Fitzsimons, J.A.; Gonzalez, E.; Kinnison, M.; Lindenmayer, D.; et al. Conserving small natural features with large ecological roles: A synthetic overview. Biol. Conserv. 2017, 211, 88-95. [CrossRef]

57. Phalan, B.; Onial, M.; Balmford, A.; Green, R.E. Reconciling Food Production and Biodiversity Conservation: Land Sharing and Land Sparing Compared. Science 2011, 333, 1289-1291. [CrossRef] [PubMed]

58. Yang, M.; Liu, Z. Agricultural land sharing/sparing and their potential effects on biodiversity. Chin. J. Eco-Agric. 2017, 25, 787-794.

59. Grass, I.; Loos, J.; Baensch, S.; Batáry, P.; Librán Embid, F.; Ficiciyan, A.; Klaus, F.; Riechers, M.; Rosa, J.; Tiede, J.; et al. Landsharing/-sparing connectivity landscapes for ecosystem services and biodiversity conservation. People Nat. 2019, 1, $262-272$. [CrossRef]

60. Folberth, C.; Khabarov, N.; Balkovic, J.; Skalsky, R.; Visconti, P.; Ciais, P.; Janssens, I.A.; Penuelas, J.; Obersteiner, M. The global cropland-sparing potential of high-yield farming. Nat. Sustain. 2020, 3, 281-289. [CrossRef]

61. Feng, Z.; Xu, X.; Zhou, J.; Gao, Y. Land sparing versus sharing framework from ecosystem service perspective. Prog. Geogr. 2016, $35,1100-1108$.

62. Jager, H.I.; Kreig, J. Designing landscapes for biomass production and wildlife. Glob. Ecol. Conserv. 2018, 16, e00490. [CrossRef]

63. Balmford, A.; Green, R.; Phalan, B. What conservationists need to know about farming. Proc. R. Soc. B Biol. Sci. 2012, 279, 2714-2724. [CrossRef] [PubMed]

64. Firbank, L.G.; Elliott, J.; Drake, B.; Cao, Y.; Gooday, R. Evidence of sustainable intensification among British farms. Agric. Ecosyst. Environ. 2013, 173, 58-65. [CrossRef]

65. Tschumi, M.; Albrecht, M.; Baertschi, C.; Collatz, J.; Entling, M.H.; Jacot, K. Perennial, species-rich wildflower strips enhance pest control and crop yield. Agric. Ecosyst. Environ. 2016, 220, 97-103. [CrossRef]

66. Lindenmayer, D.B. Conserving large old trees as small natural features. Biol. Conserv. 2017, 211, 51-59. [CrossRef]

67. Kremen, C.; Williams, N.M.; Aizen, M.A.; Gemmill-Herren, B.; LeBuhn, G.; Minckley, R.; Packer, L.; Potts, S.G.; Roulston, T.; Steffan-Dewenter, I.; et al. Pollination and other ecosystem services produced by mobile organisms: A conceptual framework for the effects of land-use change. Ecol. Lett. 2007, 10, 299-314. [CrossRef] [PubMed]

68. Leibold, M.A.; Holyoak, M.; Mouquet, N.; Amarasekare, P.; Chase, J.M.; Hoopes, M.F.; Holt, R.D.; Shurin, J.B.; Law, R.; Tilman, D.; et al. The metacommunity concept: A framework for multi-scale community ecology. Ecol. Lett. 2004, 7, 601-613. [CrossRef]

69. Fahrig, L. Effects of habitat fragmentation on biodiversity. Annu. Rev. Ecol. Evol. Syst. 2003, 34, 487-515. [CrossRef]

70. Kazemi, H.; Klug, H.; Kamkar, B. New services and roles of biodiversity in modern agroecosystems: A review. Ecol. Indic. 2018, 93, 1126-1135. [CrossRef]

71. Duarte, G.T.; Santos, P.M.; Cornelissen, T.G.; Ribeiro, M.C.; Paglia, A.P. The effects of landscape patterns on ecosystem services: Meta-analyses of landscape services. Landsc. Ecol. 2018, 33, 1247-1257. [CrossRef]

72. Ogilvie, C.M.; Deen, W.; Martin, R.C. Service crop management to maximize crop water supply and improve agroecosystem resilience: A review. J. Soil Water Conserv. 2019, 74, 389-404. [CrossRef]

73. Duchene, O.; Vian, J.; Celette, F. Intercropping with legume for agroecological cropping systems: Complementarity and facilitation processes and the importance of soil microorganisms. A review. Agric. Ecosyst. Environ. 2017, 240, 148-161. [CrossRef]

74. Bengtsson, J. Biological control as an ecosystem service: Partitioning contributions of nature and human inputs to yield. Ecol. Entomol. 2015, 401, 45-55. [CrossRef]

75. Costanza, R. The value of the world's ecosystem services and natural capital. Nature 1997, 387, 253-260. [CrossRef]

76. Zou, Y.; de Kraker, J.; Bianchi, F.J.J.A.; Xiao, H.; Huang, J.; Deng, X.; Hou, L.; van der Werf, W. Do diverse landscapes provide for effective natural pest control in subtropical rice? J. Appl. Ecol. 2020, 57, 170-180. [CrossRef]

77. Kremen, C. Managing ecosystem services: What do we need to know about their ecology? Ecol. Lett. 2005, 8, 468-479. [CrossRef] 
78. Landis, D.A. Designing agricultural landscapes for biodiversity-based ecosystem services. Basic Appl. Ecol. $2017,18,1-12$. [CrossRef]

79. Odum, H.T.; Odum, E.P. The energetic basis for valuation of ecosystem services. Ecosystems 2000, 3, 21-23. [CrossRef]

80. Bommarco, R.; Kleijn, D.; Potts, S.G. Ecological intensification: Harnessing ecosystem services for food security. Trends Ecol. Evol. 2013, 28, 230-238. [CrossRef] [PubMed]

81. Pankhurst, C.E.; Magarey, R.C.; Stirling, G.R.; Blair, B.L.; Bell, M.J.; Garside, A.L. Management practices to improve soil health and reduce the effects of detrimental soil biota associated with yield decline of sugarcane in Queensland, Australia. Soil Till. Res. 2003, 72, 125-137. [CrossRef]

82. Manevski, K.; Laerke, P.E.; Jiao, X.; Santhome, S.; Jorgensen, U. Biomass productivity and radiation utilisation of innovative cropping systems for biorefinery. Agric. For. Meteorol. 2017, 233, 250-264. [CrossRef]

83. Fu, B.; Zhang, L. Land-use change and ecosystem services: Concepts, methods and progress. Prog. Geogr. 2014, 33, 441-446.

84. Duffy, J.E. Why biodiversity is important to the functioning of real-world ecosystems. Front. Ecol. Environ. 2009, 7, 437-444. [CrossRef]

85. Stoate, C.; Boatman, N.D.; Borralho, R.J.; Carvalho, C.R.; de Snoo, G.R.; Eden, P. Ecological impacts of arable intensification in Europe. J. Environ. Manag. 2001, 63, 337-365. [CrossRef] [PubMed]

86. Bennett, A.J.; Bending, G.D.; Chandler, D.; Hilton, S.; Mills, P. Meeting the demand for crop production: The challenge of yield decline in crops grown in short rotations. Biol. Rev. 2012, 87, 52-71. [CrossRef] [PubMed]

87. Wan, N.F.; Cai, Y.M.; Shen, Y.J.; Ji, X.Y.; Wu, X.W.; Zheng, X.R.; Cheng, W.; Li, J.; Jiang, Y.P.; Chen, X.; et al. Increasing plant diversity with border crops reduces insecticide use and increases crop yield in urban agriculture. eLife 2018, 7, e35103. [CrossRef]

88. Qiu, J.; Carpenter, S.R.; Booth, E.G.; Motew, M.; Zipper, S.C.; Kucharik, C.J.; Loheide, S.P.I.; Turner, A.G. Understanding relationships among ecosystem services across spatial scales and over time. Environ. Res. Lett. 2018, 13, 054020. [CrossRef]

89. Struik, P.C.; Kuyper, T. Sustainable intensification in agriculture: The richer shade of green. A review. Agron. Sustain. Dev. 2017, 37, 39. [CrossRef]

90. Pretty, J. Intensification for redesigned and sustainable agricultural systems. Science 2018, 362, 908. [CrossRef]

91. Mankowski, J.; Pudelko, K.; Kolodziej, J. Cultivation of Fiber and Oil Flax (Linum usitatissimum L.) in No-tillage and Conventional Systems. Part I. Influence of No-tillage and Conventional System on Yield and Weed Infestation of Fiber Flax and the Physical and Biological Properties of the Soil. J. Nat. Fibers 2013, 10, 326-340. [CrossRef]

92. Zhao, X.; Liu, S.; Pu, C.; Zhang, X.; Xue, J.; Ren, Y.; Zhao, X.; Chen, F.; Lal, R.; Zhang, H. Crop yields under no-till farming in China: A meta-analysis. Eur. J. Agron. 2017, 84, 67-75. [CrossRef]

93. Grafton, R.Q.; Williams, J.; Perry, C.J.; Molle, F.; Ringler, C.; Steduto, P.; Udall, B.; Wheeler, S.A.; Wang, Y.; Garrick, D.; et al. The paradox of irrigation efficiency. Science 2018, 361, 748-750. [CrossRef]

94. Zhu, Z.; Jin, J. Fertilizer use and food security in China. Plant Nutr. Fertitizer Sci. 2013, 19, 259-273.

95. Internatioal Fertilizer Industry Association. Fertilizer, Climate Change and Enhancing Agricultural Productivity Sustainably. 2009. Available online: https://www.fertilizer.org/images/Library_Downloads/2009_ifa_climate_change.pdf (accessed on 12 November 2019).

96. Ministry of Ecology and Environment of the People's Republic of China, National Bureau of Statistics, Ministry of Agricultural and Rural Affairs of the People's Republic of China. The First National Census of Pollution Bulletin. 2010. Available online: http: / / www.stats.gov.cn/tjsj/tjgb/qttjgb / qgqttjgb/201002/t20100211_30641.html (accessed on 12 October 2019).

97. Luo, X.; Liao, J.; Hu, L.; Zang, Y.; Zhou, Z. Improving agricultural mechanization level to promote agricultural sustainable development. Trans. Chin. Soc. Agric. Eng. 2016, 32, 1-11.

98. Kleijn, D.; Winfree, R.; Bartomeus, I.; Carvalheiro, L.G.; Henry, M.; Isaacs, R.; Klein, A.; Kremen, C.; M'Gonigle, L.K.; Rader, R.; et al. Delivery of crop pollination services is an insufficient argument for wild pollinator conservation. Nat. Commun. 2015, 6. [CrossRef]

99. Saturni, F.T.; Jaffe, R.; Metzger, J.P. Landscape structure influences bee community and coffee pollination at different spatial scales. Agric. Ecosyst. Environ. 2016, 235, 1-12. [CrossRef]

100. Lichtenberg, E.M.; Kennedy, C.M.; Kremen, C.; Batary, P.; Berendse, F.; Bommarco, R.; Bosque-Perez, N.A.; Carvalheiro, L.G.; Snyder, W.E.; Williams, N.M.; et al. A global synthesis of the effects of diversified farming systems on arthropod diversity within fields and across agricultural landscapes. Global. Chang. Biol. 2017, 23, 4946-4957. [CrossRef]

101. Woodcock, B.A.; Garratt, M.P.D.; Powney, G.D.; Shaw, R.F.; Osborne, J.L.; Soroka, J.; Lindström, S.A.M.; Stanley, D.; Ouvrard, P.; Edwards, M.E.; et al. Meta-analysis reveals that pollinator functional diversity and abundance enhance crop pollination and yield. Nat. Commun. 2019, 10. [CrossRef]

102. Wittman, H.; Chappell, M.J.; Abson, D.J.; Kerr, R.; Blesh, J.; Hanspach, J.; Perfecto, I.; Fischer, J. A social-ecological perspective on harmonizing food security and biodiversity conservation. Reg. Environ. Chang. 2017, 17, 1291-1301. [CrossRef] [PubMed]

103. Kremen, C.; Merenlender, A.M. Landscapes that work for biodiversity and people. Science 2018, 362, 304. [CrossRef] [PubMed]

104. Raebel, E.M.; Merckx, T.; Feber, R.E.; Riordan, P.; Thompson, D.J.; Macdonald, D.W. Multi-scale effects of farmland management on dragonfly and damselfly assemblages of farmland ponds. Agric. Ecosyst. Environ. 2012, 161, 80-87. [CrossRef]

105. Hvenegaard, G.T. Validating bird diversity indicators on farmland in east-central Alberta, Canada. Ecol. Indic. 2011, 11, 741-744. [CrossRef] 